\title{
EDGE EFFECT ON A TREE COMMUNITY IN AN ARAUCARIA FOREST FRAGMENT IN BRAZIL
}

\author{
Ângela Maria Klein Hentz ${ }^{1 *}$ Ana Paula Dalla Corte ${ }^{1}$, Carlos Roberto Sanquetta ${ }^{1}$, Christopher Thomas Blum $^{1}$, \\ Guilherme Camacho Cadori ${ }^{1}$
}

Universidade Federal do Paraná, Centro de Ciências Florestais e da Madeira, Curitiba, Paraná, Brasil. angelakhentz@gmail.com*; anapaulacorte@gmail.com; sanquetta@ufpr.br; ctblum.ufpr@gmail.com; gccadori@ hotmail.com

Recebido para publicação: 28/06/2017 - Aceito para publicação: 03/10/2017

\begin{abstract}
The forest fragmentation is considered to be one of the main processes causing negative effects on biodiversity. Among its effects, it causes changes in the composition and diversity of forest species through the replacement of original species by other adapted for disturbance areas. Therefore, the objective of this research was to evaluate the impact of the edge effect over richness and abundance of tree species in an Araucaria Forest fragment in southern Brazil. Data from two plots of 1 hectare each submitted to annual inventories (since 1995) were used. Individuals with diameter at breast height $(1.30 \mathrm{~m})$ over $10 \mathrm{~cm}$ were measured, and their geographical coordinates were recorded. These individuals were plotted over a grid where the plots were divided into subplots of $10 \times 100 \mathrm{~m}$ after the edge. In addition, the edge influence over mortality and ingrowth was assessed. The existence of influence over richness and abundance of tree individuals was observed, mainly in the region up to $30 \mathrm{~m}$ from the edge. The edge effect influences mainly the ingrowth in comparison to the mortality, and both plots responded differently to edge effects.

Keywords: Forest fragmentation; Atlantic forest; floristic composition; ecological group; cluster analysis.
\end{abstract}

\section{Resumo}

Efeito de borda sobre uma comunidade arbórea em um fragmento de Floresta com Araucária no Brasil. A fragmentação das florestas é considerada um dos principais processos que causam efeitos negativos sobre a biodiversidade. Entre eles estão alterações na composição e diversidade de espécies florestais pela substituição de espécies originais por outras adaptadas a áreas de distúrbios. Dessa forma, o objetivo deste trabalho foi avaliar o impacto do efeito de borda sobre a riqueza e abundância de espécies arbóreas em um fragmento de Floresta com Araucária no sul do Brasil. Foram utilizados dados de duas parcelas de 1 hectare cada, coletados em inventários anuais (desde 1995). Os indivíduos com diâmetro à altura do peito (1,3 m) acima de $10 \mathrm{~cm}$ foram medidos, e suas coordenadas espaciais foram coletadas. Os indivíduos foram plotados em um grid de parcelas subdivididas em parcelas de 10x100 m após a borda. Além disso, o efeito de borda sobre o ingresso e mortalidade do indivíduo foi analisado. Também, foi observada a influência da borda sobre a riqueza e abundância de indivíduos, principalmente nos primeiros $30 \mathrm{~m}$ após a borda. $\mathrm{O}$ efeito de borda influenciou principalmente os ingressos, em comparação com a mortalidade, e as duas parcelas apresentaram diferentes respostas ao efeito de borda.

Palavras-chave: Fragmentação florestal; Mata Atlântica; composição florestal; grupos ecológicos; Análise de Cluster.

\section{INTRODUCTION}

The Atlantic Forest is considered one of the 25 hotspots of biodiversity in the world, and one of the greatest centers of species endemism (RIBEIRO et al., 2011; RIBEIRO et al., 2009). Several studies have pointed the low quantity of remaining fragments of this biome and a major part of them have less than 50 hectares of extension (RIBEIRO et al., 2009). Over this perspective, these fragments are subjected to the negative effects of forest fragmentation and one of great importance is the edge effect. This effect is the main threat to the conservation of these forest fragments (NASCIMENTO et al., 2010). With forest fragmentation, the edge environment grows drastically, while it is only found in a small scale in primary forests (LAURANCE; VASCONCELOS, 2009).

In the edge region, the biotic and abiotic changes are more pronounced, creating different microenvironments and an abrupt transition between the forest and surrounding areas (FERRAZ, 2011). Among the abiotic alterations, it is possible to mention: reduction of relative humidity, rise of temperature, greater 
luminosity and wind, increase of evapotranspiration which decreases the flux of water in the soil, changes in biomass decomposition and carbon liberation to the atmosphere (MURCIA, 1995; LAURANCE; VASCONCELOS, 2009). Other than that, it is observed a higher intensity and occurrence of forest fires due to the proximity with non-forest areas, which were favored because of the presence of conditions as less moisture in the soil, as well the high intensity of sun light and winds that can spread the flames (CUMMING et al., 2012).

At the biotic level, the effects can be either direct or indirect. Some of these effects are: mortality and/or ingrowth increase, density increase of pioneer species trees' and lianas, easily invasive species propagation and disease transmission, variations in biomass and carbon stock, and late sapling density reduction (LAURANCE; VASCONCELOS, 2009; PAULA et al., 2011; RIGUEIRA et al., 2012). Fragmentation, mainly in areas with high proportion of edges, affects pollination systems, leveraging generalist diurnal pollinators and hermaphrodite trees (LOPES et al., 2009). In addition, the fragments are exposed to a ruderal plant's seed rain and alterations in the soil seed bank, which can modify the composition and structure of the remaining fragment, and can lead the fragments to initial stages of succession (TABARELLI et al., 2008; SOUSA et al., 2017).

Edge effect generates a range of alterations in the communities, and the understanding of its impacts, as well as its extension and magnitude, becomes important for conservation strategies development (MURCIA, 1995; NASCIMENTO et al., 2010). In Atlantic Forest regions, several edge effect influence distances can be found: $50 \mathrm{~m}$ for forest environments is the most common value (MURCIA, 1995), also observed in Araucaria Forest areas (FONTOURA et al., 2006). This distance is shorter for Atlantic Rainforest (sensu strictu), $30 \mathrm{~m}$ (RIGUEIRA et al., 2012). There is no consensus in the literature regarding these values, and the edge effect varies according to different assessed characteristics and forest type (HARPER et al., 2005).

Because of that, there are still some pending questions, such as: Can edges affect species richness and abundance, as well as the distribution of ecological groups inside the forest? Furthermore, how far inside the forest is possible to observe edge effects? Therefore, the objective of this paper is to assess the influence of edge effect at species richness and abundance in a fragment of Araucaria Forest along 18 years.

\section{MATERIAL AND METHODS}

\section{Study area}

The survey was performed in two permanent plots located in an Experimental Station (25 34' $18^{\circ}$ ' S and $50^{\circ} 05^{\prime} 56^{\prime} \mathrm{W}$ ) in the municipality of São João do Triunfo, central-south region of Paraná State - Brazil, at $780 \mathrm{~m}$ over the sea. The region climate, according to Köppen classification, is Cfb (temperate always moist), with annual average temperature between 17 and $18^{\circ} \mathrm{C}$ (IAPAR, 2012). Annual average precipitation ranges from 1,400 to $1,600 \mathrm{~mm}$; annual relative humidity varies from $75 \%$ to $85 \%$; and annual average evapotranspiration ranges from 800 to $900 \mathrm{~mm}$ (IAPAR, 2012). An association of Red-Yellow Argisols, Tb Haplic Cambisols and Red Latosols occurs in the Experimental Station (EMBRAPA, 2013).

The São João do Triunfo Experimental Station (EESJT) has a total area of approximately 33 hectares over the Araucaria Forest, also known as Mixed Ombrophilous Forest (IBGE, 2012). The fragment was divided in 30 1ha plots (100x100m), which are part of the Long Term Ecological Research Program (PELD) Site 9, and four of them have been measured annually since 1995. Thus, in this study, we used these annual inventories records, from 1995 to 2013, in which all measurement events were performed in July. Two of the four plots (named as A and B) were selected for this study due to their proximity to the edge. Both of them present one side facing a non-forest site. A plot borders an unpaved road (around $8 \mathrm{~m}$ wide) followed by a homogenous plantation of Pinus sp., and it is represented by Araucaria angustifolia (Bertol.) Kuntze and hardwood species in the canopy; and B plot is neighboring to an agricultural area, and is represented by hardwood species, mainly Ocotea porosa (Nees \& Mart.) Barroso, predominating in the canopy. More information about the EESJT site and the data collections performed along the years in this area are presented in Sanquetta et al. (2014).

\section{Data collection and processing}

Data from forest inventories gathered in the study area from 1995 to 2013 were charted into electronic spreadsheets. They were composed by all trees over $10 \mathrm{~cm}$ of diameter at breast height (DBH). Ingrowth and dead individuals were recorded every year. Geographical coordinates of each tree and the plot's limits in vector shape were taken during the inventories.

Plots A and B were divided into 10 subplots according to distances to the edge (figure 1). Each subplot had $10 \times 100 \mathrm{~m}$, totaling $1,000 \mathrm{~m}^{2}$, and was identified by a number and the code letter for the plot. Thus, spreadsheets with the species and individuals of each subplot were generated, and exported to a geographic information system (GIS) software in the sequence. All individuals were identified by subplot. 
Besides, as it was observed from 1995 to 2013, many ingrowth had occurred, as well as a large mortality rate. Due to that, we decided to divide data into three categories: living trees - all individuals measured in 2013; ingrowth trees - those that were not included in the first inventory, but reached $10 \mathrm{~cm}$ at DBH in the next measurement events, including even individuals that died during this period; and dead trees - all that were measured during the study and were dead in some year.

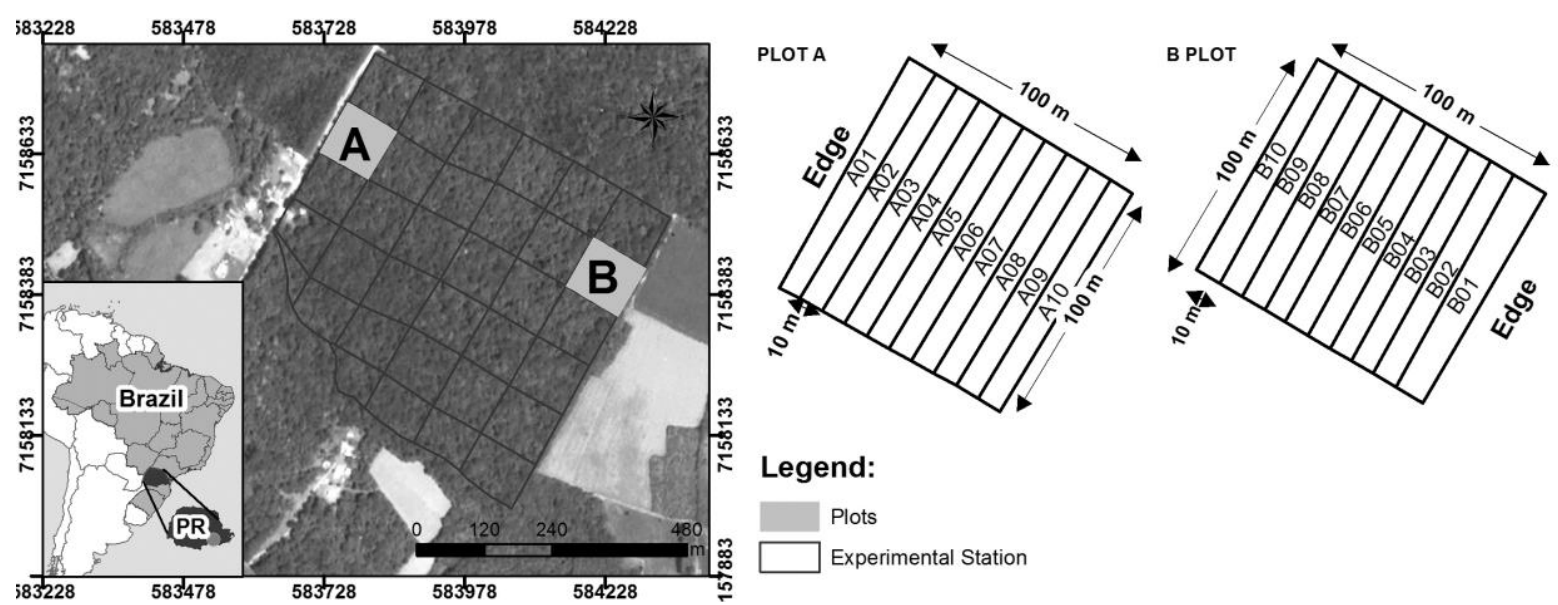

Figure 1. Location of A and B plots in the São João do Triunfo Experimental Station, PR, Brazil; and scheme of subplots of the assessed gradients.

Figura 1. Localização das parcelas A e B na Estação Experimental de São João do Triunfo, PR, e esquema de subparcelas dos gradientes analisados.

\section{Richness and abundance}

Richness was defined by the sum of species found in each subplot. As some individuals were not identified in both plots, they were recorded as a unique group, and considered as one species in the richness calculations. The same pattern was assumed for living, ingrowth and dead trees. Abundance was calculated by the sum of individuals found in the subplots.

\section{Cluster analysis}

The cluster analysis was performed by using individual's abundance for each species. Data were organized in matrices, in which each species was represented by the number of trees found in each subplot. Ward's method (minimum variance) and the Squared Euclidean distance were applied, and the values were standardized before the calculations. Statgraphics plus 5.1 was used for the cluster analysis. In order to analyze the number of groups formed, the dendrogram was halved.

\section{Ecological groups}

Species were classified according to ecological groups as described by Leitão Filho (1993): 1) Pioneers: usually short-lived and fast growing, rising in forest gaps, on the edges and open spaces, clearly dependent of high luminosity, and not occurring under dense canopy; 2) Early secondary: growing in small forest gaps or, more rarely, under dense canopy, at intermediary shade, also occurring in old forest gaps areas, next to the pioneers; 3) Late secondary/climax: rising under dense canopy, permanently shaded areas and, in this case, can be either small or large tree species, with slow growth rate that may reach the canopy or even emerge it.

Distribution of ecological groups was performed based in two categories: light demanding group (pioneers and early secondary species); and shade tolerant group (climax and late secondary species). Species found in A and B plots and their ecological groups can be found in table 1. 
Table 1. Species found in A and B plots, from 1995 to 2013, São João do Triunfo Experimental Station, Paraná, Brazil.

Tabela 1. Espécies inventariadas nas parcelas A e B, de 1995 até 2013, na Estação Experimental de São João do Triunfo, Paraná, Brasil.

\begin{tabular}{|c|c|c|c|}
\hline Family & Scientific name & Common name & EG \\
\hline Anacardiaceae & Lithrea brasiliensis Marchand & Bugreiro & $\mathrm{ES}$ \\
\hline Anacardiaceae & Lithrea molleoides (Vell.) Engl. & Bugreirinho & $\mathrm{ES}$ \\
\hline Anacardiaceae & Schinus terebinthifolius Raddi & Aroeira & $\mathrm{P}$ \\
\hline Annonaceae & Annona sp. & Ariticum & $*$ \\
\hline Aquifoliaceae & Ilex brevicuspis Reissek & Caúna & $\mathrm{LS} / \mathrm{CL}$ \\
\hline Aquifoliaceae & Ilex paraguariensis A. St.-Hil. & Erva-mate & $\mathrm{LS} / \mathrm{CL}$ \\
\hline Aquifoliaceae & Ilex theezans Mart. ex Reissek & Orelha-de-mico & $\mathrm{LS} / \mathrm{CL}$ \\
\hline Araucariaceae & Araucaria angustifolia (Bertol.) Kuntze & Pinheiro-do-paraná & $\mathrm{LS} / \mathrm{CL}$ \\
\hline Arecaceae & Syagrus romanzoffiana (Cham.) Glassman & Jerivá & $\mathrm{LS} / \mathrm{CL}$ \\
\hline Asteraceae & Moquiniastrum polymorphum (Less.) G. Sancho & Cambará & $\mathrm{P}$ \\
\hline Asteraceae & Piptocarpha angustifolia Dusén ex. Malme & Vassourão branco & $\mathrm{P}$ \\
\hline Asteraceae & Piptocarpha axillaris (Less) Baker. & Vassourão-graúdo & $\mathrm{P}$ \\
\hline Asteraceae & Vernonanthura discolor (Spreng.) H.Rob. & Vassourão-preto & $\mathrm{P}$ \\
\hline Bignoniaceae & Jacaranda puberula Cham. & Caroba & $\mathrm{ES}$ \\
\hline Canellaceae & Cinnamodendron dinisii Schwacke & Pimenteira & $\mathrm{LS} / \mathrm{CL}$ \\
\hline Celastraceae & Maytenus ilicifolia Mart. Ex. Reissek & Espinheira-santa & $\mathrm{LS} / \mathrm{CL}$ \\
\hline Celastraceae & Maytenus sp. & Espinheira & $*$ \\
\hline Clethraceae & Clethra scabra Pers. & Carne-de-vaca & $\mathrm{P}$ \\
\hline Elaeocarpaceae & Sloanea lasiocoma K. Schum. & Sapopema & $\mathrm{LS} / \mathrm{CL}$ \\
\hline Erythroxylaceae & Erythroxylum deciduum A. St.-Hil. & Cocão & $\mathrm{LS} / \mathrm{CL}$ \\
\hline Euphorbiaceae & Sapium glandulosum (L.) Morong & Leiteiro & $\mathrm{ES}$ \\
\hline Euphorbiaceae & Sebastiana brasiliensis Spreng. & Leiteirinho & $\mathrm{LS} / \mathrm{CL}$ \\
\hline Euphorbiaceae & Gymnanthes klotzschiana Müll.Arg. & Branquilho & ES \\
\hline Fabaceae & Inga sp. & Ingá & * \\
\hline Fabaceae & Lonchocarpus sp. & Rabo-de-bugiu & $*$ \\
\hline Fabaceae & Machaerium sp. & Sapuva & $*$ \\
\hline Fabaceae & Machaerium stipitatum (DC.) Vogel & Sapuvinha & $\mathrm{LS} / \mathrm{CL}$ \\
\hline Fabaceae & Mimosa scabrella Benth. & Bracatinga & $\mathrm{P}$ \\
\hline Lamiaceae & Aegiphila integrifolia (Jacq.) Moldenke & Gaioleira & $\mathrm{P}$ \\
\hline Lamiaceae & Vitex megapotamica (Spreng.) Moldenke & Tarumã & $\mathrm{LS} / \mathrm{CL}$ \\
\hline Lauraceae & Cinnamoтum amoenum (Nees et Mart.) Kosterm. & Pau-alho & ES \\
\hline Lauraceae & Nectandra grandiflora Ness et C. Mart. ex Ness & Canela-amarela & $\mathrm{LS} / \mathrm{CL}$ \\
\hline Lauraceae & Nectandra lanceolata Nees & Canela-amarela & $\mathrm{LS} / \mathrm{CL}$ \\
\hline Lauraceae & Nectandra megapotamica (Spreng.) Mez & Canela-preta & $\mathrm{LS} / \mathrm{CL}$ \\
\hline Lauraceae & Nectandra sp. & Canela-imbuia & $\mathrm{LS} / \mathrm{CL}$ \\
\hline Lauraceae & Ocotea porosa (Nees et Mart.) Barroso & Imbuia & $\mathrm{LS} / \mathrm{CL}$ \\
\hline Lauraceae & Ocotea puberula (Rich.) Nees & Canela-guaicá & $\mathrm{ES}$ \\
\hline Lauraceae & Ocotea pulchella Mart. & Canela-lageana & $\mathrm{LS} / \mathrm{CL}$ \\
\hline Lauraceae & Ocotea sp. & Canela & $\mathrm{LS} / \mathrm{CL}$ \\
\hline Malvaceae & Luehea divaricata Mart. & Açoita-cavalo & ES \\
\hline Meliaceae & Cedrela fissilis Vell. & Cedro & ES \\
\hline Meliaceae & Trichilia elegans A. Juss. & Pau-de-ervilha & $\mathrm{LS} / \mathrm{CL}$ \\
\hline Myrtaceae & Blepharocalyx salicifolius (Kunth) O. Berg & Murteira & $\mathrm{LS} / \mathrm{CL}$ \\
\hline Myrtaceae & Campomanesia guazumifolia (Cambess.) O. Berg & Sete-capotes & $\mathrm{LS} / \mathrm{CL}$ \\
\hline Myrtaceae & Campomanesia xanthocarpa (Mart.) O.Berg & Guabiroba & $\mathrm{LS} / \mathrm{CL}$ \\
\hline Myrtaceae & Eugenia handroana D. Legrand & \multicolumn{2}{|c|}{ Guamirim-vermelhı LS/CL } \\
\hline Myrtaceae & Eugenia involucrata DC. & Cerejeira & $\mathrm{LS} / \mathrm{CL}$ \\
\hline Myrtaceae & Eugenia uniflora L. & Pitanga & $\mathrm{LS} / \mathrm{CL}$ \\
\hline Myrtaceae & Myrceugenia euosma (O. Berg) D. Legrand & Guamirim-branco & $\mathrm{LS} / \mathrm{CL}$ \\
\hline Myrtaceae & Myrcia splendens (Sw.) DC. & Guamirim-chorão & $\mathrm{ES}$ \\
\hline Myrtaceae & Myrcia sp. & Guamirim & $\mathrm{LS} / \mathrm{CL}$ \\
\hline Myrtaceae & Psidium sp. & Araçá & $\mathrm{LS} / \mathrm{CL}$ \\
\hline
\end{tabular}




\begin{tabular}{|c|c|c|c|}
\hline Primulaceae & Myrsine coriacea (Sw.) R.Br. ex Roem. et Schult. & Capororoquinha & $\mathrm{P}$ \\
\hline Primulaceae & Myrsine umbellata Mart. & Capororocão & ES \\
\hline Proteaceae & Roupala brasiliensis Klotz. & Carvalho & ES \\
\hline Rhamnaceae & Hovenia dulcis Thunb. & Uva-do-japão & ES \\
\hline Rosaceae & Prunus brasiliensis (Cham. et Schltdl.) D. Dietr. & Pessegueiro-bravo & ES \\
\hline Rutaceae & Zanthoxylum kleinii (R. S. Cowan) P.G. Waterman & Juvevê-branco & LS/CL \\
\hline Rutaceae & Zanthoxylum rhoifolium Lam. & Mamica-de-cadela & LS/CL \\
\hline Salicaceae & Casearia decandra Jacq. & Guaçatunga & LS/CL \\
\hline Salicaceae & Casearia obliqua Spreng. & Guaçatunga-vermel & LS/CL \\
\hline Salicaceae & Xylosma pseudosalzmanii Sleumer & Sucará & $\mathrm{LS} / \mathrm{CL}$ \\
\hline Sapindaceae & Allophylus edulis (A.St.-Hil. et al.) Hieron. ex Niederl. & Chal-chal & $\mathrm{LS} / \mathrm{CL}$ \\
\hline Sapindaceae & Cupania vernalis Cambess. & Cuvatã & $\mathrm{LS} / \mathrm{CL}$ \\
\hline Sapindaceae & Matayba elaeagnoides Radlk. & Miguel-pintado & $\mathrm{LS} / \mathrm{CL}$ \\
\hline Solanaceae & Solanum mauritianum Scop. & Tabaco & $\mathrm{P}$ \\
\hline Solanaceae & Solanum sp. & $*$ & $*$ \\
\hline Styracaceae & Styrax leprosus Hook. et Arn. & Pau-de-remo & ES \\
\hline Symplocaceae & Symplocos celastrinea Mart. & Pau-de-anta & ES \\
\hline Symplocaceae & Symplocos sp. & Maria-mole miúda & $*$ \\
\hline Winteraceae & Drimys brasiliensis Miers. & Cataia & $\mathrm{LS} / \mathrm{CL}$ \\
\hline
\end{tabular}

$\mathrm{EG}=$ Ecological group. $\mathrm{P}=$ Pioneer; $\mathrm{ES}=$ Early secondary; $\mathrm{LS} / \mathrm{CL}=$ Late secondary/climax. The symbol * means that information is not available.

\section{RESULTS}

Species richness and abundance of living individuals were slightly higher in $\mathrm{B}$ than A (figure 2). Richness in B plot was higher at the edge (subplot 0-10 m) than in the inner part. For A plot, richness showed almost no variation, with slight increase in the subplot $20-30 \mathrm{~m}$ from the edge, while in the other subplots richness was close to 20 species. For abundance, B plot presented higher values than A in total but not in all subplots. Moreover, the subplots near the edge $(0-10 \mathrm{~m})$ in B had more individuals than the same subplot in A (172 and 87). The second subplot $(10-20 \mathrm{~m})$ in B plot was also higher than the average. In the other subplots (>20 m), abundance values were around 80 and 50 for A and B plots.

Species richness for ingrowth on both plots was higher in subplots closer to the edge (figure 2). Subplot A02 (10-20 m) was the richest of this plot; however, species number gradually declines to the subsequent subplots. First subplot of B contrasts to the others, with twice species. For ingrowth abundance, subplot B01 was much higher than the others, meaning that the high density of ingrowth occurred only in the edge of this plot. For A plot, there was a gradual decrease in ingrowth abundance, but, different from richness, subplot A01 presented more individuals than $\mathrm{A} 02$.

Mortality in plot A did not show a pattern neither for species richness, nor for the abundance of individuals (figure 2). Indeed, in the first four subplots of A plot (A01-A04), richness of dead individuals was lower than in the other subplots. Abundance did not differ much among subplots. In B plot, however, mortality was accentuated in the subplot B01 (0-10 m from the edge), as well as a much higher species richness of dead individuals. 

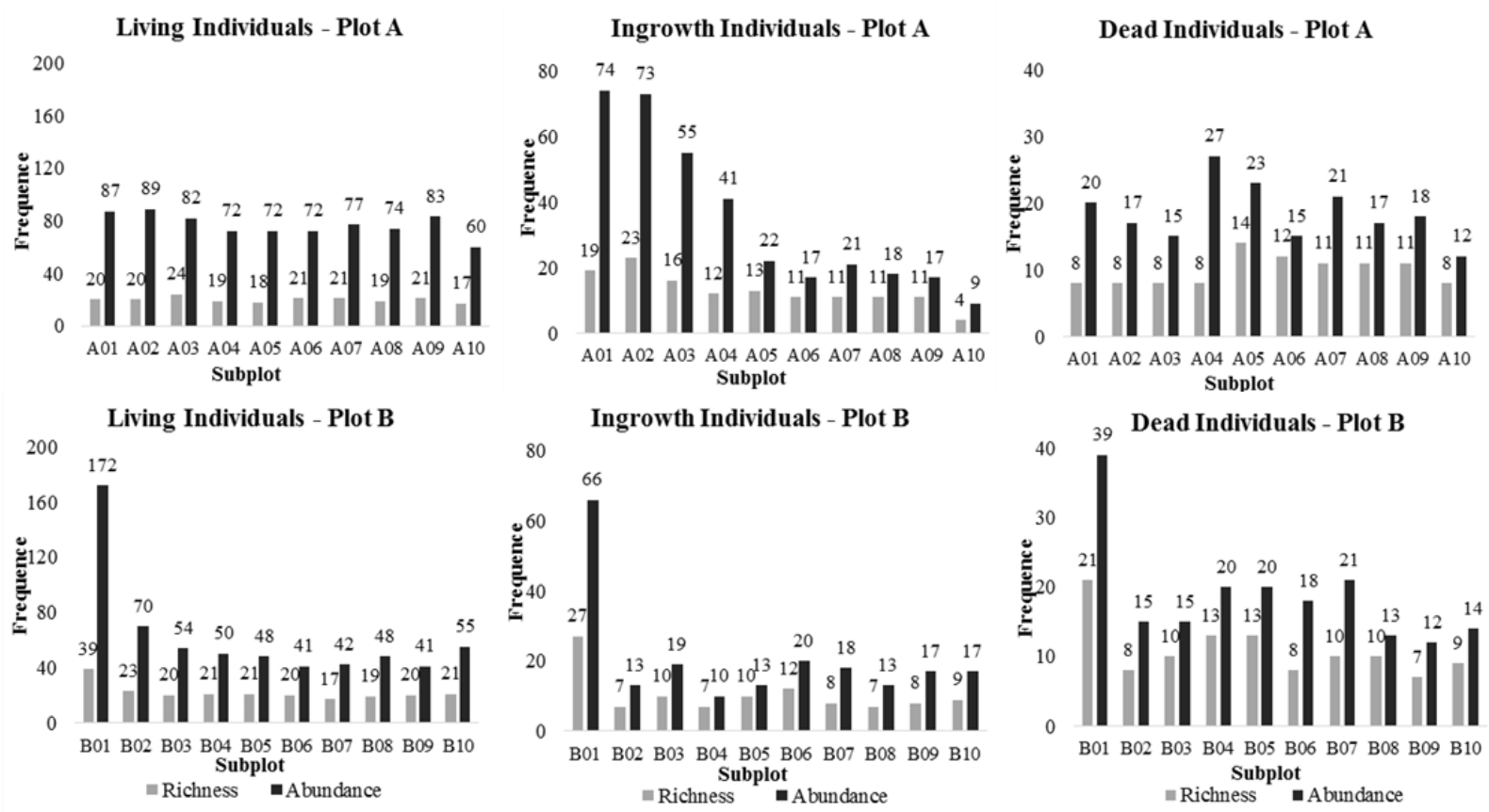

Figure 2. Richness and abundance of living, ingrowth and dead individuals in A and B plots, according to distance from the edge.

Figura 2. Riqueza e abundância de indivíduos vivos, ingressos e mortos nas parcelas A e B, de acordo com a distância de borda.

Cluster analysis of living individuals in A and B plots (figure 3) allowed grouping the first subplot right after the edge with its subsequent two subplots. Three groups were formed in A: A01, A02 and A03; A04, A08, A09 and A10; and A05, A06 and A07. For B plot, we found three groups: B01, B02 and B03; B04, B06 and $\mathrm{B} 05$; and B07, B08, B10 and B09.
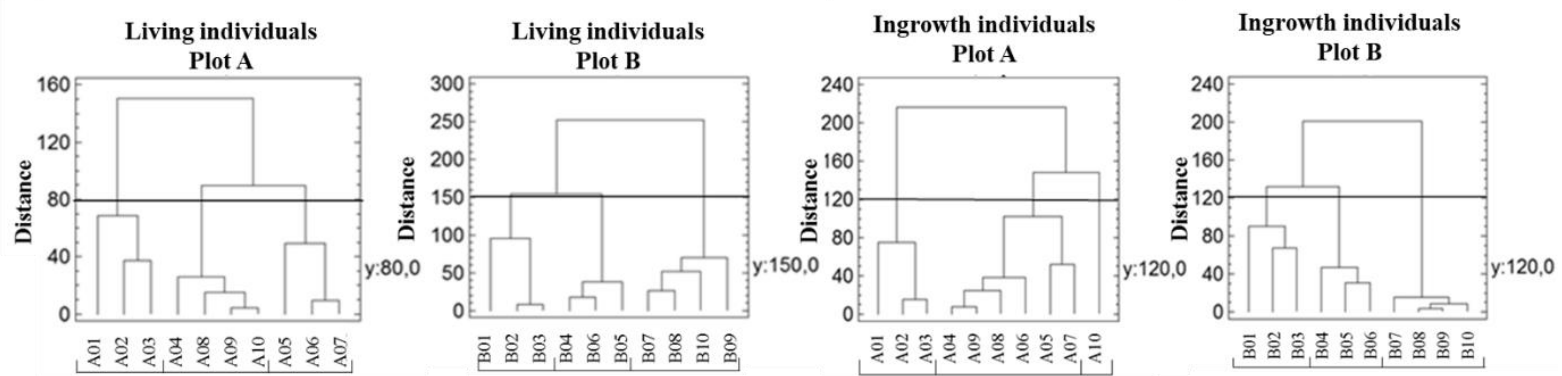

Figure 3. Cluster analysis of living and ingrowth individuals in A and B plots.

Figura 3. Análise de Cluster dos indivíduos vivos e ingressos nas parcelas A e B.

Ingrowth data (figure 3) in A plot resulted in three groups: group A01, A02 and A03; group A04, A09, A08, A06, A05 and A07; and the last group formed only by A10. Ingrowths in B were also separated in three groups: group B01, B02 and B03; group B04, B05 and B06; and group B07, B08, B09 and B10. Grouping analysis of dead individuals did not provide results to similarity among subplots related to the edge; therefore they are not presented.

Ecological group distribution for living individuals (figure 4) in the subplots closer to the edges had a higher presence of light demanding individuals, for both plots. Climax species have occupied predominantly the inner portions of the plot A, differently from B plot. Light demanding group was the predominant up to subplot A03, and after this, the shade tolerant group was improved. High density of both groups was registered in edge of B plot. Pioneer and early secondary species were located mainly in the edges of B. On the other hand, climax and late secondary species were distributed throughout the whole plot with a higher occurrence in the edge. 

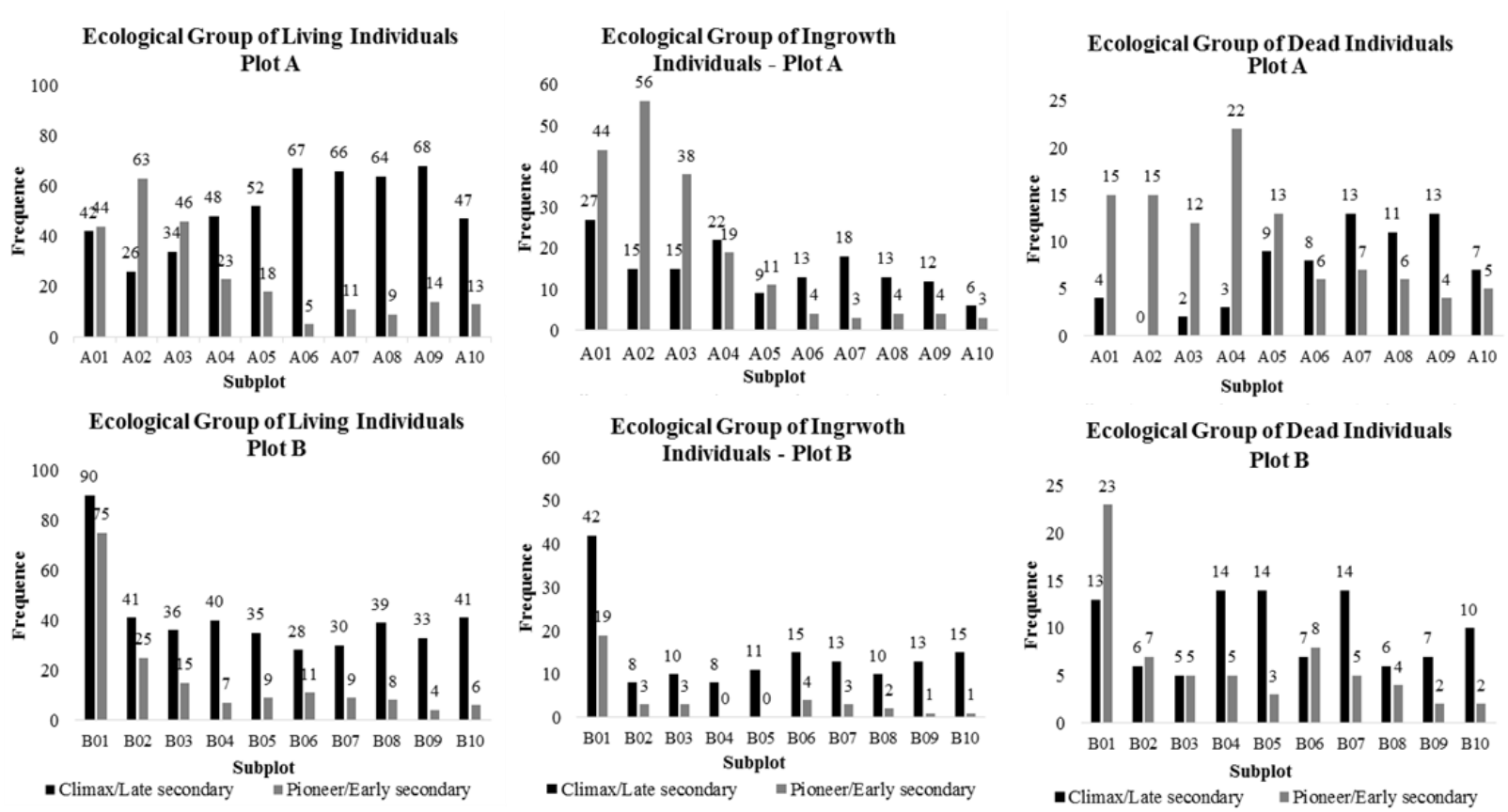

Figure 4. Distribution of living, ingrowth and dead individual's ecological groups in A and B plots.

Figura 4. Distribuição de grupos ecológicos dos indivíduos vivos, ingressos e mortos nas parcelas A e B.

For ingrowth individuals (figure 4) of A, the closer to the edge, the higher was the proportion of light demanding individuals. However, the shade tolerant species also represented part of the ingrowth in the edge. Again, it was noticed that there is an inversion of which group is predominant, and this inversion occurs between A04 and A05 plots. The light demanding group prevailed until A04, and the shade tolerant group became predominant from A05. For B plot, the subplot closer to the edge (B01) presented a high density of both groups, but the climax/late secondary group was predominant. In the rest of the plot, there was an increase of shade tolerant species towards the interior of the plot, as well as the reduction of light demanding species. Thus, the results for ingrowth followed the same pattern previously mentioned for the living individuals, except for one subplot of B near to the edge.

In A plot (figure 4), the closer to the edge, the higher was the mortality of light demanding species, while in the inner part mortality was higher for shade tolerant species. There was an increase of mortality of light demanding species closer to the edges in $\mathrm{B}$, while a higher mortality of shade tolerant species was observed in the rest of the plot.

\section{DISCUSSION}

Results for B plot, with higher richness near to the edges, agree with trends registered by other authors (HARPER et al., 2005; BERNACCI et al., 2006). In some cases, according to Fontoura et al. (2006), the edge itself $(0 \mathrm{~m})$ showed to be distinct from the rest of the forest, similarly to what happened with plot B. Ingrowth richness and abundance proved that higher richness in the edge was not related to a pre-existing process, once there was a higher abundance of regenerating individuals in these regions, also indicated by Fontoura et al. (2006). Fast regeneration is important as it reduces the contrast of the edge over the time, due to the renovation of the forest, and it is commonly present after the edge's stabilization period (HARPER et al., 2005).

Accentuated increase of ingrowth in the edge of plot B is possibly related to the higher amount of light that crosses this area, as a result of the surrounding matrix (WATLING et al., 2011). Plot B edge faces the southeast direction (sunlight is likely to be reduced); however, as the area right after the edge is used for agriculture, it promotes high level of luminosity. On the other hand, edge of plot A faces the northeast direction, where solar luminosity is higher, but it is also reduced due to a forest plantation beyond the road, which can be acting as a barrier for winds.

The higher mortality on the edge of plot B was expected, as observed by other authors (LAURANCE et al., 2007; LAURANCE; VASCONCELOS; 2009). In plot A, we did not notice the same pattern. Since mortality is considered a process that occusr mostly in the first years after the fragmentation (LAURANCE et al., 2007), it 
is possible that plot A presented high mortality rates years ago, and now there is a stabilization, since we still notice a high regeneration close to the edge.

Distinct patterns between the two plots can also be associated to the edge age (HARPER et al., 2005), being the magnitude and distance influence more pronounced in recent edges. Considering the three edge development stages (MATLACK, 1994) - formation, reorganization of physical gradients and expansion of edge area - it is possible to suggest that the immediate effects of fragmentation have passed over the years, once mortality rates are lower in those areas and regeneration is higher, in order to supply the previous mortality. In addition, we can suppose that plot A has never faced intense edge effects due to the presence of arboreal vegetation near the plot edge. Edge effect was clearly observed in plot B, with high mortality and ingrowth rates, most relevant in the external subplot (B01). It was not possible to identify the exact age of the edges. However, by analyzing Landsat imagery, it was registered the same road present nowadays in the limit with plot A as in 1986, as well as the same agricultural area in the limit of plot B. These findings indicate that these edges must be at least 25 years old by the end of the evaluated period.

Cluster analysis indicates that the first three subplots were grouped due their richness and abundance similarities. The rest of the subplots were not always grouped with their neighbors. These results are coherent based on the analyses of richness and abundance performed separately. As previously observed, subplot B01 differs drastically from the others, even though it was grouped with B02 and B03 (in this group B01 is the most distinct subplot). Thus, edge effects seem to be present up to $30 \mathrm{~m}$ towards the fragment inner portion. This result differs from other authors, like Murcia (1995) and Fontoura et al. (2006), in which the edge effects can influence the sites up to $50 \mathrm{~m}$ far from the edge. On the other hand, it converged concerning the abundance of pioneer species in the edge of Dense Atlantic Forests, according to Rigueira et al. (2012). This result can be related to the availability of light, which is observed in high levels between 20-40 m inside of recent fragments (MURCIA, 1995), while in older edges higher levels of luminosity are restrict to $10 \mathrm{~m}$ from the edges (RIGUEIRA et al., 2012). So, these plots are possibly at different response stages regarding fragmentation.

The number of individuals in the light demanding group was higher next to the edges, as expected, due higher availability of light as well the dominance of this species in the seed bank (SOUSA et al., 2017). This predominance remains until subplot A02 and A03 as same as abundance in other studies (BERNACCI et al., 2006; LAURANCE et al., 2007; FERRAZ, 2011; RIGUEIRA et al., 2012). This can be explained by the increase of mortality rate of trees near the fragments edges, that increased the amount of forest gaps, favoring pioneer species over non-pioneer species (LAURANCE; VASCONCELOS; 2009).

Presence of shade tolerant species in the edges is similar to other studies (BERNACCI et al., 2006; FONTOURA et al., 2006). This situation can be explained by the medium/advanced vegetation stage of these plots, where the canopy is comprised by pioneer species, and the shade generated by them enables suitable conditions to the development of shade tolerant species. In the same way, ingrowth and mortality rates are possibly stabilizing, because these are temporary events (LAURANCE et al., 2007). In plot B, where the number of shade tolerant species in the edges is higher, this can also be a reflex of a previous process, considering that in this study we only assessed ingrowth with $\mathrm{DBH}$ greater than $10 \mathrm{~cm}$, and therefore these individuals might be present in the forest for several years before reaching the minimum DBH criterion, especially considering the shade tolerant species that generally present slower growth compared to pioneers (BUDOWSKI, 1965; SOUSA et al., 2017; CHEN et al., 2017). If the tree was smaller than $10 \mathrm{~cm}$ at DBH and the sapling bank would be considered, the trend could be different because they would have emerged recently.

Ecological group analysis of dead individuals showed the same trend for living and ingrowth individuals. In other words, it was found high mortality rates of light demanding species in the edge and of shade tolerant species towards the plot's interior. This difference might likely be an effect of higher density of these species in this region, combined to the fact that these species present lower longevity (BUDOWSKI, 1965), as well are more susceptible to wind damage, since they have lower wood density (CHEN et al., 2017), and consequently mortality.

\section{CONCLUSIONS}

In this study, we concluded that:

- The edges have effects over richness and mainly over the abundance of arboreal individuals in Araucaria Forest ecosystem;

- The edge effects were stronger over ingrowth individuals;

- Edge effects were greater up to $30 \mathrm{~m}$ from the edge towards the forest inner part;

- There were edge effects over ecological group distribution, once there was greater concentration of pioneer and initial secondary species near the edges. 


\section{ACKNOWLEDGEMENTS}

The authors of this paper are thankful to the of Long Term Ecological Research Program (PELD) Site 9 for providing the data of this research, and to the Coordination for the Improvement of Higher Education Personnel (CAPES) for providing the first author's scholarship.

\section{REFERENCES}

BERNACCI, L. C.; FRANCO, G. A. D. C.; ÁRBOC, G. F.; CATHARINO, E. L. M.; DURIGAN, G.; METZGER, J. P. O Efeito da Fragmentação Florestal na Composição e Riqueza de Árvores na Região da Reserva Morro Grande (Planalto de Ibiúna, SP). Revista do Instituto Florestal, São Paulo, v. 18, p. 121-166, 2006.

BUDOWSKI, G. N. Distribution of Tropical American Rain Forest Species in the Light of Succession Processes. Turrialba, Costa Rica, v. 15, n. 1, p. 40-42, 1965.

CHEN, L.; XIANG, W.; WU, H.; LEI, P.; ZHANG, S.; OUYANG, S.; DENG, X.; FANG, X. Tree growth traits and social status affect the wood density of pioneer species in secondary subtropical forest. Ecology and Evolution, v.7, p. 1-12, 2017.

CUMMING, G. S.; SOUTHWORTH, J.; RONDON, X. J.; MARSIK, M. Spatial complexity in fragmenting Amazonian rainforests: Do feedbacks from edge effects push forests towards an ecological threshold?. Ecological Complexity, Oxford, 11, 67-74, 2012.

FERRAZ, A. C. P. Efeitos de Borda em Florestas Tropicais Sobre Artrópodes, com Ênfase nos Dípteros Ciclorrafos. Oecologia Australis, Rio de Janeiro, v. 15, n. 2, p. 189-198, 2011.

FONTOURA S. B.; GANADE G.; LAROCCA, J. Changes in Plant Community Diversity and Composition Across an Edge Between Araucaria Forest and Pasture in South Brazil. Revista Brasileira de Botânica, São Paulo, v. 29, n. 1, p. 79-91, 2006.

HARPER, K. A.; MACDONALD, S. E.; BURTON, P. J.; CHEN, J.; BROSOFSKE, K. D.; SAUNDERS, S. C.; EUSKIRCHEN, E. S.; ROBERTS, D.; JAITEH, M. S.; ESSEEN, P. Edge influence on forest structure and composition in fragmented landscapes. Conservation Biology, v. 19, n. 3, p. 768-782, 2005.

IAPAR - INSTITUTO AGRONÔMICO DO PARANÁ. Cartas Climáticas do Estado do Paraná. Available in: http://www.iapar.br/modules/conteudo/conteudo.php?conteudo=677, Acessed in: 20/06/2016.

IBGE - INSTITUTO BRASILEIRO DE GEOGRAFIA E ESTATÍSTICA. Manual técnico da vegetação brasileira. Rio de Janeiro: IBGE, $2^{a}$ ed. 2012, 275 p.

LAURANCE, W. F.; NASCIMENTO, H. E. M.; LAURANCE, S. G.; ANDRADE, A.; EWERS, R. M.; HARMS, K. E.; LUIZÃO, R. C. C.; RIBEIRO, J. E. Habitat Fragmentation, Variable Edge Effects, and the Landscape-Divergence Hypothesis. PLOS ONE, v. 10, n. 2, p. 1-8, 2007.

LAURANCE, W. F.; VASCONCELOS, H. L. Consequências Ecológicas da Fragmentação Florestal na Amazônia. Oecologia Brasiliensis, Rio de Janeiro, v. 13, p. 434-451, 2009.

LEITÃO FILHO, H. F. Ecologia da mata atlântica em Cubatão. São Paulo: UNESP/UNICAMP. 1993, 184 p.

LOPES, A. V.; GIRÃO, L. C.; SANTOS, B. A.; PERES, C. A.; TABARELLI, M. Long-term Erosion of Tree Reproductive Trait Diversity in Edge-dominated Atlantic Forest Fragments. Biological Conservation, v. 142, n. 6, p. 1154-1165, 2009.

MATLACK, G. R. Vegetation dynamics of the forest edge: trends in space and sucessional time. Journal of Ecology, v. 82, p. 113-123, 1994.

MURCIA, C. Edge effects in fragmented forests: implications for conservation. Trends in Ecology \& Evolution, v.10, p. 58-62, 1995.

NASCIMENTO, M. I.; POGGIANI, F.; DURIGAN, G.; LEMMA, A. F.; SILVA FILHO, D. F. Eficácia de Barreira de Eucaliptos na Contenção do Efeito de Borda em Fragmento de Floresta Subtropical no Estado de São Paulo, Brasil. Scientia Forestalis, Piracicaba, v. 86, n. 86, p. 191-203, 2010. 
PAULA, M. D.; COSTA, C. P. A.; TABARELli, M. Carbon storage in a fragmented landscape of Atlantic forest: the role played by edge-affected habitats and emergent trees. Tropical Conservation Science, v. 4, p. 349-358, 2011.

RIBEIRO, M. C.; MARTNSEN, A. C.; METZGER, J. P.; TABARELLI, M.; SCARANO, F.; FORTIN, M. J. The Brazilian Atlantic Forest: A Shrinking Biodiversity Hotspot. In: ZACHOS, F. E.; HABEL. J. C. (eds). Biodiversity Hotspots: Distribution and Protection of Conservation Priority Areas. Berlin: Springer-Verlag, 2011, p. 405-434.

RIBEIRO, M. C.; METZGER, J. P.; MARTEnSEN, A. C.; PONZONI, F. J.; HIROTA. M. M. The Brazilian Atlantic Forest: How Much is Left, and how is the Remaining Forest Distributed? Implications for Conservation. Biological Conservation, v. 142, n. 6, p. 1141-1153, 2009.

RIGUEIRA, D. M. G.; MOLINARI, A. L. M.; MARIANO, D. L. S.; REIS, R. M.; PORTUGAL, A. B.; SANTANA, N. S.; SANTOS, R. A. Influência da distância da borda e do adensamento foliar sobre a abundância de plantas pioneiras em um fragmento de floresta tropical submontana na Estação Ecológica de Wenceslau Guimarães (Bahia, Brasil). Acta Botanica Brasilica, Belo Horizonte, v. 26, n. 1, p. 197-202, 2012.

SANQUETTA, C. R.; CORTE, A. P. D.; RODRIGUES, A. L.; MOGNON, F. Floresta com Araucária: Pesquisas Ecológicas de Longa Duração. 1. ed. Curitiba: Multi-graf, 2014. v. 1. 298 p.

SANTOS, H. G.; JACOMINE, P. K. T.; ANJOS, L. H. C.; OLIVEIRA, V. A.; LUBRERAS, J. F.; COELHO, M. R.; ALMEIDA, J. A.; CUNHA, T. J. F.; OLIVEIRA, J. B. Sistema Brasileiro de Classificação de Solos. Brasília: Embrapa, $3^{\mathrm{a}}$ ed. 2013, 353 p.

SOUSA, T. R.; COSTA, F. R. C.; BENTOS, T. V.; LEAL FILHO, N.; MESQUITA, R. C. G.; RIBEIRO, I. O. The effect of forest fragmentation on the soil seed bank of Central Amazonia. Forest Ecology and Management, v. 393, p. 105-112, 2017.

TABARELLI, M.; LOPES, A. V.; PERES, C. Edge-effects Drive Tropical Forest Fragments Towards an Earlysuccessional System. Biotropica, v. 40, n. 6, p; 657-661, 2008.

WATLING, J. I.; NOWAKOWSKI, A. J.; DONNELLY, M. A.; ORROCK, J. L. Meta-analysis Reveals the Importance of Matrix Composition for Animals in Fragmented Habitat. Global Ecology and Biogeography, v. 20, n. 2, p. 209-217, 2011. 